\title{
Ankle Joint Pathlology of Car Drivers and Passengers Case Report
}

\author{
Dr. med. Jacek Karski ${ }^{1}$, Prof. Tomasz Karski ${ }^{2}$, Dr. Katarzyna Karska ${ }^{3}$ \\ Dr. med. Jarosław Pyrc ${ }^{4}$ \\ ${ }^{1}$ J. Karski, Medical University, Lublin, Poland, ${ }^{2}$ T. Karski, Vincent Pol University, Lublin, Poland \\ ${ }^{3}$ K. Karska, Medical University, Lublin, Poland \\ ${ }^{4}$ J. Pyrc, Medical University of Carl Gustav, Dresden, Germany \\ tmkarski@gmail.com
}

Received Date: May 26, 2017

Accepted Date: June 07, 2017

Published Date: June 15, 2017

Abstract: Deformations of the feet of children and feet pain syndromes of adults are very common, more likely among women. In children and youth we can observe: $\mathbf{1 / v a l g u s ~ o r ~ p l a n o ~ - ~ v a l g u s ~ f e e t ~ d e f o r m i t y , ~} 2$ / congenital or neurological deformations of feet, $\mathbf{3}$ / Köhler's disease among girls wearing improper shoes. Among adults can appear: 1/ insufficiency and pain of frontal part of feet connected with limited toes flexion, 2/ valgus deformity of the big toes (hallux valgus), $\mathbf{3}$ / "insufficiency and pain syndrome of ankle joint" - till now not been described. The pain is due to the instability of this joint. In our study, we describe this special type of foot insufficiency - "instability of ankle joint" and pain syndrome as a result of "permanent distortion of ankle joint" - left leg by drivers and right leg by passengers in countries with "right traffic rules".

Keywords: Chronic distortion of the ankle joint. Chronic foot pain syndrome

\section{INTRODUCTION}

The weakness of muscles is the main reason for dysfunction of musculoskeletal system in the opinion of many physiotherapists. The authors of presented publication do not agree with this opinion. Such theory is not correct and not evidenced. Our opinion is, that the main reason for musculoskeletal disorders are shortenings, in orthopedics language called "contractures" of ligaments, tendons, muscles, capsules. That is the reason for asymmetric growth and deformation among children and function asymmetry among adults with different types of pain. The detailed description of different contractures has been done by Professor Hans Mau, also called in German "Siebenersyndrom" $(14,15,18)$.

\section{FEET PROBLEMS OF CHILDREN AND OF ADULTS}

There are many different factors influencing insufficiencies of the feet associated with the pain. In our orthopedic practice we can notice:

1 / flat foot deformation of children and of teenager

2/ limited plantar flexion of the big toe and other toes, usually among adults suffering from forefoot pain, detected by flexion toe test (figure 1a, 1b, 1c, 1d) 
These are the phases of deformations of the toes:

a/ losing plantar flexion of the big toe and all other toes during propulsion,

b/ forefoot pain,

c/ swelling of dorsum of pedis over heads of metatarsal II and III bones,

d/ thickening, hardening, forefoot plantar callosity,

e/ callosity on dorsum of the toes,

3/ halluces valgi - very frequent among women (figure 1a),

4/ foot insufficiency among girls - Köhler dissease,

5/ hereditary and neurogenic disorders of the foot in children and adults.

In literature we can find the description of instability of the ankle joint, but not followed by causes such as described in this article. We describe such syndrome among drivers using mostly the small cars. In patients we noticed limited movement of dorsal flexion of the foot, pain, swelling, gait restriction. The cause of this clinical symptoms is permanent distortion of ankle joint. The problem was present for first time 16 years ago (T. Karski) on the lectures in Orthopedic School in Siebenlehn, in Germany.

\section{MATERIAL: THE GROUP OF PATIENTS WITH INSUFFICIENCY OF ANKLE JOINT}

We treated in period of 16 years, 26 patients $(n=26)$ with chronic insufficiency due to the distortion of the ankle joint leading to limitation of dorsal flexion of the foot and pain syndrome. The causes of the distortion of ankle joint appears in the moment of getting out from the car. This pathology is seen on the left ankle joint of car drivers (22 cases) or the right ankle joint of passengers (4 cases) in countries with "right traffic rules". This illness is a new syndrome of foot pathology which has not been indicated or published yet. Surely, these symptoms were noticed by many doctors who treated only the symptoms - the pain - but was not considered the etiological factors of the disease. In past time, in most of the cases, the therapy was not proper and not successful. The doctors interpreted the walking difficulty, the pain and the swelling of the soft tissues mostly as a peripheral vascular disease.

\section{ANAMINESIS AND CLINICAL SYMPTOMS}

Anamnesis and clinical examination had to established that the reason for insufficiency of the ankle joint was a chronic distortion of the joint while getting out of the car - mostly among people using a small car (fig. 2, 3). The size of the car plays a very important role and will be described as followed. While getting out of the car the driver after opening the cars door puts the left leg first and next puts the whole bodyweight on the left leg and its ankle joint, making the extensive rotation movement of the body on the foot situated on the ground. In this moment the ankle joint is in dorsal flexion of $0^{\circ}-5^{\circ}-10^{\circ}$ and is full stabilized. In this position, when talus between both malleoli is very stable situated comes to the rotation movement and to distortion of the ankle joint. Repeated distortion of the ankle joint over weeks, months and years causes - loosening of tibio-fibular syndesmosis and as result appears instability of this joint. In examination of the stability of the left ankle joint we can find the loosening even among people with temporary good function of the foot.

In advanced clinical cases, we noticed swelling of the joint area and mainly of the sinus tarsi and Achilles tendon. Patients try to avoid this pain and start to walk on tip toes (in pes equinus position). This causes an overstress 
now to the triceps surae and the calcaneal tendon (Achilles tendon). Now we see a next stage of foot pathology. Appears a progressed pain in $\mathrm{m}$. triceps surae and tarsus region. The developed illness takes three to four years. The previous diagnosis, before consultation in our Out-Patient Clinic, of the all ours patients was not proper and therefore the patients received insufficient and improper treatment. In most cases the first diagnosis was - peripheral vascular disease or vein insufficiency. As a result the anticoagulant drugs were recommended but did not give a positive effects. Swelling and pain of joint do not disappeared.

On the contrary - our theory focused on prevention to avoid rotation movement of the body while getting out of the car in every patient give the positive effect - disappearing of pain and diminishing of swelling.

\section{DESCRIPTION OF THE CASES.}

\section{Case No 1}

Tymoteusz D. (figure 4, 5), 37 years old, history number 790410, diagnosed 6th of August 2014. He complained about foot pain, sinus tarsi and region of calcaneal tendon. Until meeting with the authors of the article he received insufficient treatment because of inadequate diagnosis. The examination in Rehabilitation Center in Krasnobród (south east part of Poland) revealed swelling of the region of ankle joint and malleolus region, connected with instability of the ankle joint. The patient reported to often drive a small car during his job. We noticed that he often gets out of the car on the left foot and it was a reason for rotation distortion of ankle joint, next instability of this joint and pain.

We recommended to get off the car on both feet and make foot exercises - plantar and dorsal flexion. The symptoms regressed and with further examination this patient was healed, very happy and without any problems.

\section{Case No 2}

Patient Przemyslaw W. (figure 6a, 6b, 7a, 7b, 8), born 10.07.1949, 65 years old, history number 490710, diagnosed in Lublin 25th of August 2015

Patient complained about pain in the left foot. During examination we noticed swelling with thickening of soft tissue in sinus tarsi region. He reported to have difficulty putting on shoes and walking. For four years he was treated for chronicle venous insufficiency by vascular surgery doctor. In the last three weeks of this treatment he received anticoagulant injections (clexane s.c.) without improvement - no less swelling, no less pain and no less difficulty while walking. Therefore, all symptoms of illness remained unchanged.

The X-ray showed no pathology either of bones, neither of other anatomical structures. In our clinical examination the instability of ankle joint was diagnosed. The anamnesis proved our theory. As a teacher he drove to different schools daily by car. We diagnosed chronic rotation distortion of left ankle joint which caused incorrect getting out of the car. The patients' with overweight - $100 \mathrm{~kg}$. We recommended to change the way of getting off the car. Additionally, we recommended elevation of the whole leg and exercises for the foot. After a few days, patient reported - calling the doctor - the reduction of the swelling and of the pain while walking. He was able to walk without restriction. He said - he is very happy and thankful.

\section{Case No 3}

Andrzej W. (figure 6a, 6b, 7a, 7b, 8), Born 21.09.1941, 75 years old. History No 410921. The patient has had problems with his left foot and left knee for many years. In the years of 2010 to 2011 he was treated in orthopedic department and had an operation - in August 2011- on the left knee. Unfortunately - it was no improvement 


\section{Ankle Joint Pathlology of Car Drivers and Passengers Case Report}

after the knee surgery. The 3rd of September 2016 was the first consultation in our Out Patient Clinic. We diagnosed chronic distortion of the left ankle joint and left knee which were caused by incorrect getting out of the car. We recommended changing the procedure of getting off the car and elevation of the whole leg as an exercise of the left foot.

After a few days the pain of knee reduced and the ankle pain disappeared.

\section{Case No 4}

Bogumiła W. 72 years old, born 7.11.1944. History number 441107. Patient complained about swelling and pain of her right foot. She were very often as a passenger of the patient No 3. We diagnosed chronic distortion of the right ankle joint which was caused by an incorrect way of getting out of the car many times a day. We recommended changing it. Additionally, we recommended the elevation (high position) of the whole leg and foot exercises. After two months patient reported regress of pain while walking. Now she was able to walk every distance.

\section{Case No 5}

Wojciech K. 42 years old, Born 13.07.1974, History number 740713. Diagnosed in 2011. Patient has complained about pain and swelling of the left foot and region of calcaneal tendon for 5 years. He was not able to walk. Every step was with limping. After recommendation of previous doctors - using different medicaments, bandaging or walking in equines position, the pain remained.

During the consultation in our Clinical Praxis exact anamnesis and clinical examination was done and was found the chronic distortion of the left ankle joint and its instability. We recommended changing of getting off the car - now on both legs and in therapy - dorsal and plantar flexion exercises, many times every day. In next consultation - was found that the symptoms regressed and after 2 months he was able to walk properly. We repeated the examination after 5 years and noticed the patient had no more troubles walking. He told us - he admitted remembering about the proper way of getting off the car.

\section{Case No 6}

Kamil R. 25 years old, Born 2.07.1991, History number 910702, He has complained about pain in left foot and swelling for two years. The patient was not able to walk without pain. He has been consulted by different doctors. Because of the inadequate diagnosis the treatment was insufficient. The first consultation in Lublin was in 2013. During the examination swelling of the ankle joint caused by joint instability was detected. We recommended improving the getting off the car and additional foot exercises. After three months the symptoms regressed. The patient was able to walk every distance without pain.

\section{Case No 7}

Kunegunda T.K.W. 75 years old. Born 3.10.1942. History number 421003. She has complained about pain in right foot and swelling on the Achilles and tarsus region and swelling in right knee region for 4 years. She was seen by many doctors, but was not given the proper diagnosis and the introduced therapy by medicine drugs was without result. She was examined by the authors (T. Karski) on 5th May 2017. Full instability of right knee and of right ankle joint have been found. The talus bone was fully instable between both malleoli. Even the examination of this joint was painful. In anamnesis was clear up - the patient used the car every day as a 


\section{Ankle Joint Pathlology of Car Drivers and Passengers Case Report}

passenger of her husband. She used to get of the car on the right leg and made many times by every day rotation distortion of right knee and right ankle joint. We recommended exercises for the right knee and for the right ankle joint and getting out from the car on proper way - on both legs without rotation movement of the body.

\section{TREATMENT AND PROPHYLAXIS}

In the therapy it is very important to eliminate the causative reasons of distortion of the ankle joint, this means avoiding rotation movement during getting off the car or in other similar activities, for example during working in kitchen, in shop, in sport. In therapy we recommended to get out the car on both legs and both feet. Also important are exercises - extension and plantar flexion of the foot especially together with hydrotherapy. Next, in treatment we recommend laser therapy, diadynamic therapy, jonoforesis, local kryotherapy. Long years of observations enable us to noticed the positive effects of this therapy in every case of patients with pain syndrome of ankle joint. The results in all our patients were positive because the effect in therapy was connected with the rules of prophylaxis.

\section{DisCUSSION}

The complaints of pain in one foot or both feet appear relatively often and are a domain of podology. Mostly these are seen in patients with deformities being the following: pes planum, pes plano - valgus, hallux valgus or halluces valgi $(2,7,8,10,11,12,13,16,17,18)$. Often the pain is located on the fore foot which is because of limitation of plantar flexion of toes of feet, which we can check with the flexion test $(3,4,5,6$, 9). Some symptoms are a result of unadjusted shoes. Next to these known aspects of pathology of foot, the authors added new theory / conception of the sickness. The authors described a group of patients with chronic pain caused by permanent distortion of ankle joint. The anatomy / structure of ankle joint is very specific - trochlear tali is with bigger diameter in front part than in back part (Fig. 11,12). Such anatomy enables blockage of dorsal flexion of the foot which provides stabilization of ankle joint during every step for example during hiking. Without this specific aspect of trochlea tali, there would not be any mountaineers and probably not even any mountains on the world, because only specific build of the talus bone enables going up on stairs and on mountains. In this study of our patients the mechanism of ankle joint destabilization was known perfectly. This knowledge is very important for every driver in every country, to draw their attention to prophylaxis.

So far, we could not find any publication on the world literature describing the instability of ankle joint caused by getting off the car.

\section{CONCLUSION}

1) We described a new pathology syndrome of the ankle joint, the chronic distortion caused by rotation movement made during getting out the car.

2) These abnormalities are affecting the left foot of driver and right foot of passenger in countries with "right traffic rules".

3) Similar mechanisms can be detected in jobs and in various activities which provoke rotation of trunk on the stabilized foot. Problems appear regarding the feet and the knees on the same side.

4) The instability of the left ankle joint of driver happens while getting off the car, when the foot is in dorsal 
Ankle Joint Pathlology of Car Drivers and Passengers Case Report

flexion and the stabilized ankle joint on ground will be rotated. This leads to tension and elongation of the synostosis tibio - fibulare, what is the cause of loosening of the ankle joint. This destabilization is followed by serious consequences - swelling, pain, troubles walking, especially walking up the stairs, hill and mountains.

5) In the therapy we advise - kinesiotherapy, massage in water, laser, diadynamic. As well as a proper way of getting off the car - both legs and both feet without any rotation movement of the trunk.

6) The general prevention of the distortion of the left ankle joints in drivers and right ankle joint in passenger is very important. This should be the aim of every country's Medical Service. Especially drivers making frequent short distances and using the small car should be educated about this problem.

\section{REFERENCES}

1. Arroyo-Hernández M, Mellado-Romero M, Páramo-Díaz P, García-Lamas L, Vilà-Rico J. : Chronic ankle instability: Arthroscopic anatomical repair. Arroyo-Hernández M, Mellado-Romero M, Páramo-Díaz P, García-Lamas L, Vilà-Rico J. Rev Esp Cir Ortop Traumatol. 2016 Dec 8. pii: S1888-4415(16)30105-9. doi: 10.1016/j.recot.2016.10.003.

2. Hurst B, Branthwaite H, Greenhalgh A, Chockalingam N.: Medical-grade footwear: the impact of fit and comfort. J Foot Ankle Res. 2017 Jan 5;10:2. doi: 10.1186/s13047-016-0184-z.

3. Karski T. - „Przydatność testu zgięcia podeszwowego palców w ocenie niewydolności stóp. Chirurgia Narządów Ruchu i Ortopedia Polska, XXXVI, 6, 1971

4. Karski T. - „Odrębność budowy i czynności stóp wrażliwych” Przegląd skórzany Nr 6/348, 18, 1975

5. Karski T. - „Testy przydatne w ocenia zagrożeń stóp” „Biomechanika i profilaktyka statycznych zniekształceń stóp" Materials from the Scientific Session. Materiały z Sesji Naukowej, Lublin, 4-5, 12, 1979, PZWL, 113-116, 1980

6. Karski T. - „Der Zehenflexionstest zur Erkennung Frühzeitiger Stadien von Funktionsstörungen und Deformitäten der Vorfusses" Beitr. Orthop. Traumat. 32/1985/, H. T., 305-307

7. Karski T. - Wrodzone i nabyte wady stóp u dzieci; Ortopedia, traumatologia i rehabilitacja narządów ruchu, pod redakcją Prof. St. Piątkowskiego, PZWL, Warszawa 1990, 217 - 220

8. Karski T., W. Konera, M. Malicki - Statische und jatrogene Knieckplattfusdeformitäten bei Kinder. Erklärung der Erscheinungen und Möglichkeiten der Therapie. Szekesfehervar, 1990, October, 4 - 6, Orthopedic Congress in Hungary. Dni Ortopedyczne Węgierskiego Towarzystwa Ortopedycznego

9. Karski T. - Działalność Zespołu Podologicznego lubelskich klinik ortopedii. Pod kierunkiem Prof. St. Piątkowskiego. Chir. Narz Ruchu i Ortop. Polska. LV, 1990, 3, 179 - 181

10. Karski T., J. Karski, S. Snela, J. Ostrowski - Knickfussdeformitäten bei Kindern mit spastischer Verkürzung der Achillessehne. Internationaler Gemeinschaftskongress, 1995, 15 - 17 Juni, Berlin, Kurzfassungen - Block 6

11. Karski J., T. Karski, S. Snela, J. Ostrowski - Fussschäden bei Kindern mit spastischer Verkürzung der Achillessehne. Orthopädieschuhtechnik 9/96, Zeitschrift für Prävention und Rehabilitation, 24-26 
Ankle Joint Pathlology of Car Drivers and Passengers Case Report

12. Karski T., M. Frelek-Karska, A. Papierkowski, J. Taczała - Foot deformities with children with cerebral palsy Annual Meeting of the Hungarian Orthopedic Association, Abstracts, 20-21, Nyiregyhaza 20-22 June 1996

13. Karski J. - Pes valgus deformities in children with spastic shortening of the Achilles tendon, Internationaler Gemeinschaftskongress, 1995, 15-17 Juni, Berlin, 266-267. Congress materials. Abstracts.

14. Karski Jacek, Tomasz Karski - "Syndrome of contractures and deformities" according to Prof. Hans Mau as the primary cause of motoric deformities in children. Case studies including deformities of hips, neck, shank and spine. Archives of Physiotherapy and Global Researches, year 2014, Volume 18, Number 2. Formerly "Zeszyty Naukowe", Copyright 2014, Vincent Pol University In Lublin, Poland, pages 15 - 23

15. Karski Tomasz, Karski Jacek - „Syndrome of Contractures and Deformities” according to Prof. Hans Mau as Primary Cause of Hip, Neck, Shank and Spine Deformities in Babies, Youth and Adults. American Research Journal of Medicine and Surgery, Volume 1, Issue 2, 2015

16. Menz HB.: Chronic foot pain in older people. Maturitas. 2016 Sep; 91:110-4. doi: 10.1016/j. maturitas.2016.06.011. Review.

17. Vaillant J, Revillet P, Sevenier AM, Juvin R.: Impact of fatigue on postural control in quiet standing in fibromyalgia. Ann Phys Rehabil Med. 2016 Sep; 59S:e124-e125. doi: 10.1016/j.rehab.2016.07.280.

18. www.ortopedia.karski.lublin.pl

\section{FIGURES}

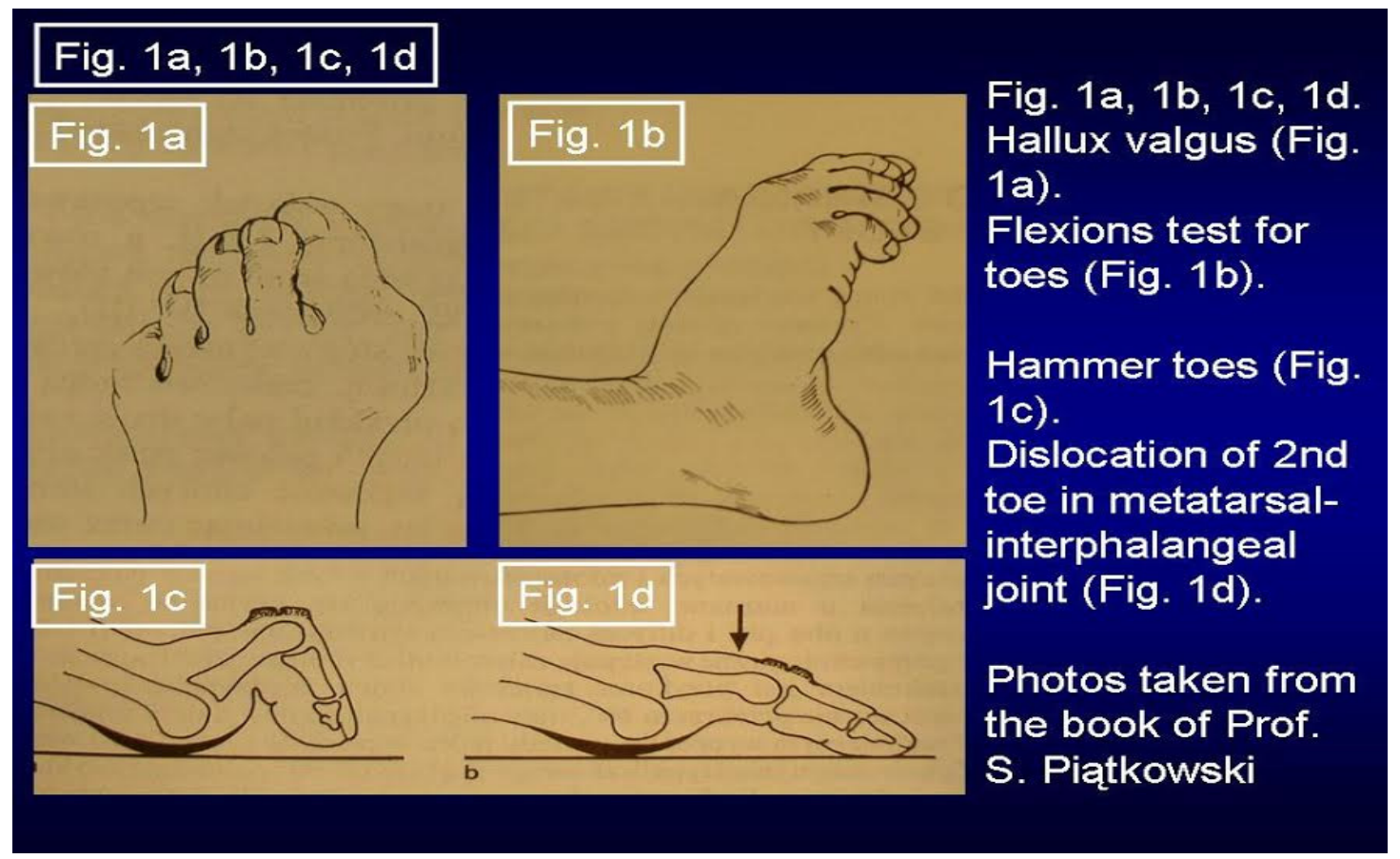

Fig.1 a, 1b, 1c, 1d. Hallux valgus (Fig. 1a). Flexions test for toes (Fig. 1b).

Hammer toes (Fig. 1c).Dislocation of 2nd toe in metatarsal-interphalangeal joint (Fig. 1d). Photos taken from the book of Prof. S. Piatkowski 


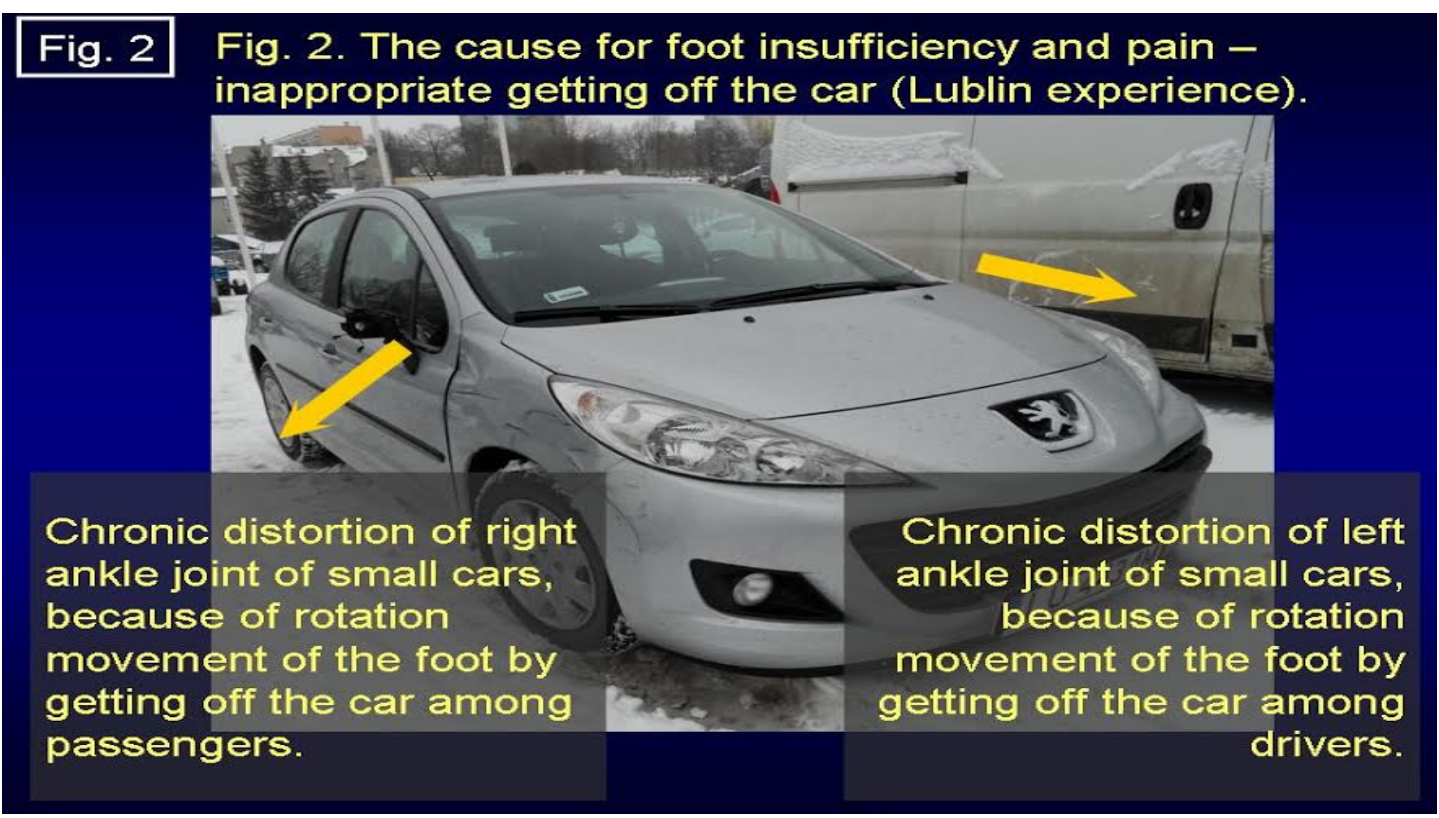

Fig. 2. The cause for foot insufficiency and pain - inappropriate getting off the car (Lublin experience). Chronic distortion of left ankle joint of small cars, because of rotation movement of the foot while getting off the car among drivers. Chronic distortion of right ankle joint of small cars, because of rotation movement of the foot by getting off the car among passengers.

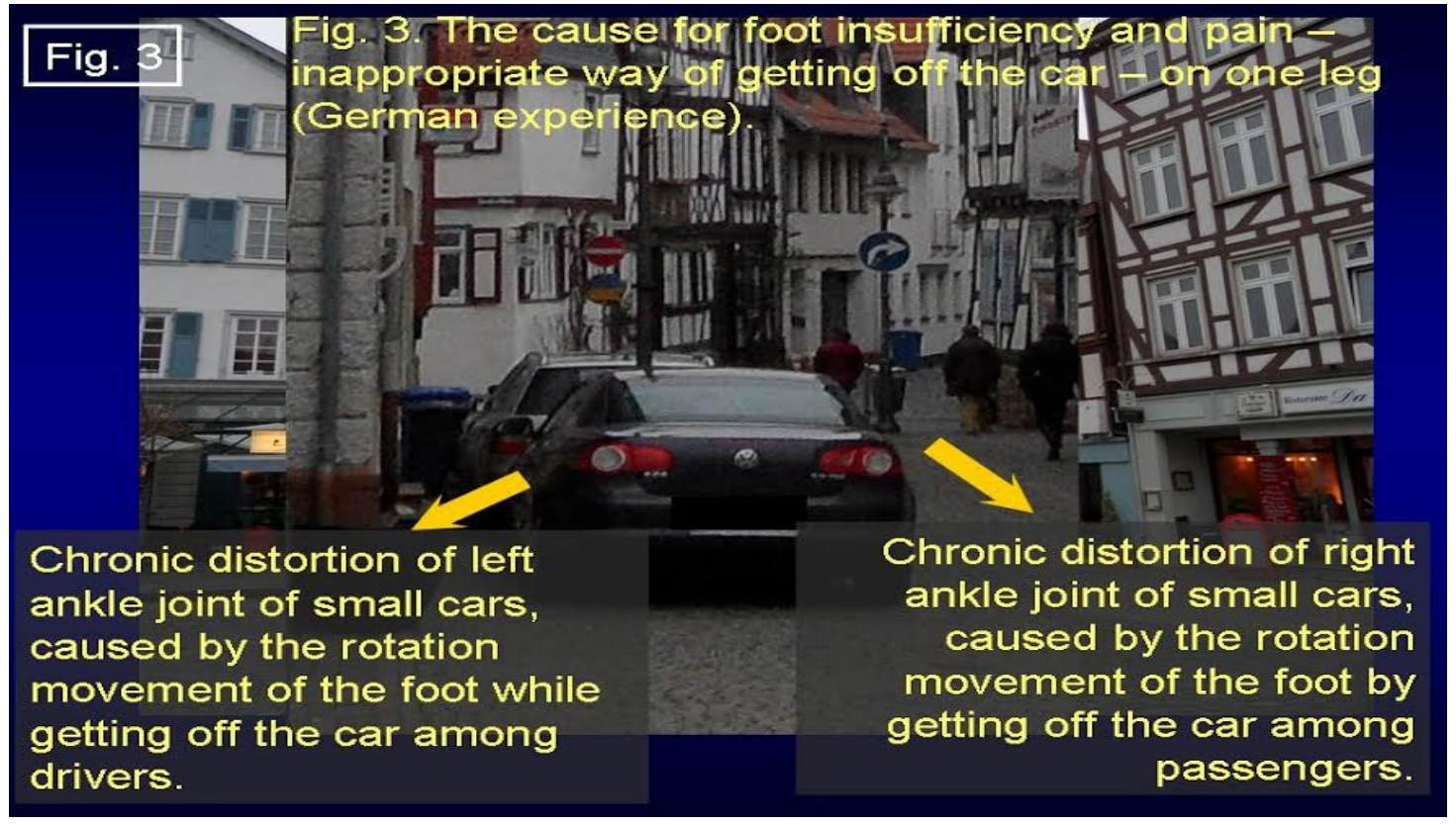

Fig. 3. The cause for foot insufficiency and pain - inappropriate way of getting off the car - on one leg (German experience). Chronic distortion of left ankle joint of small cars, caused by the rotation movement of the foot while getting off the car among drivers. Chronic distortion of right ankle joint of small cars, caused by the rotation movement of the foot by getting off the car among passengers. 


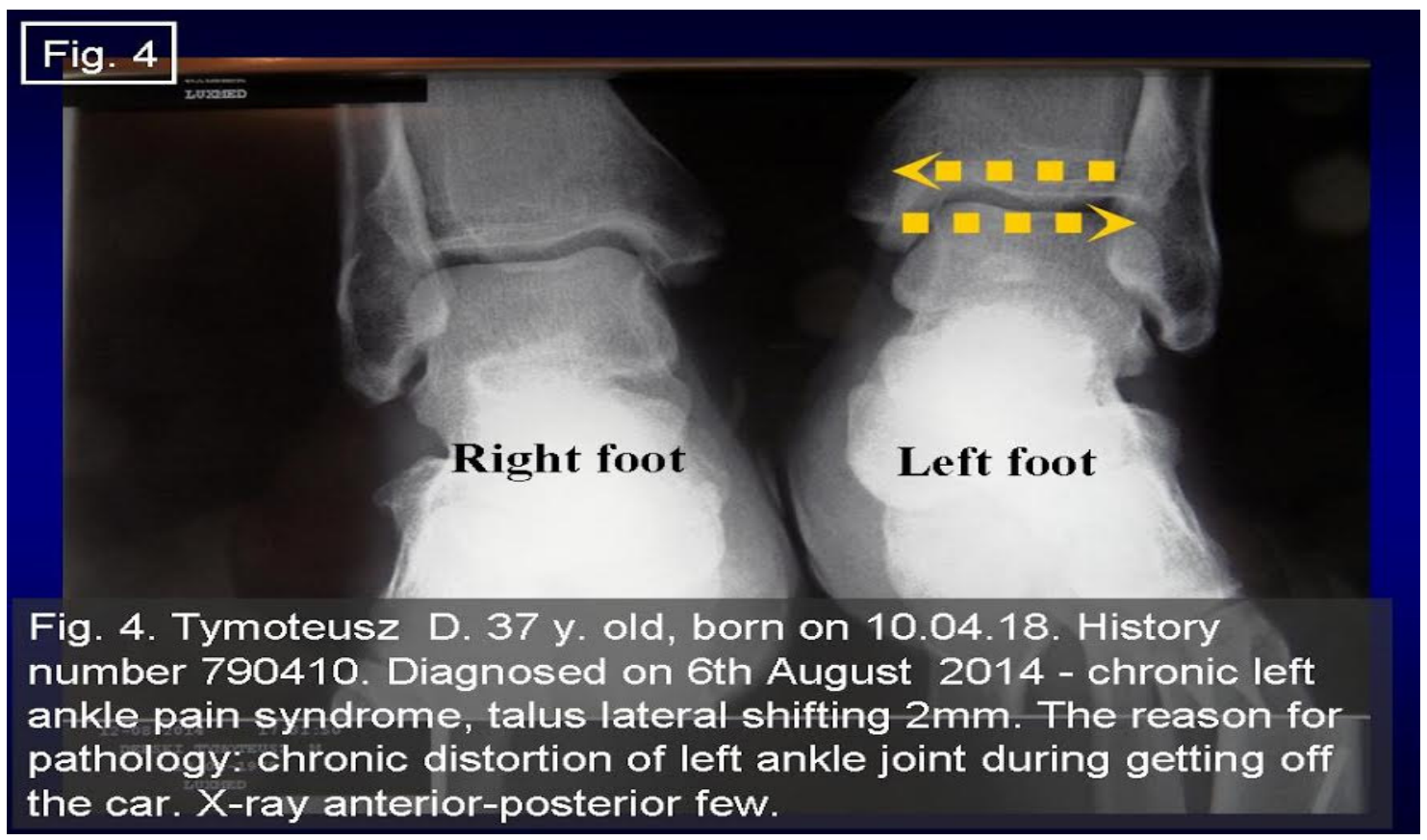

Fig. 4. Tymoteusz D. 37 y. old, born on 10.04.18. History number 790410. Diagnosed on 6th August 2014 - chronic left ankle pain syndrome, talus lateral shifting $2 \mathrm{~mm}$. The reason for pathology: chronic distortion of left ankle joint during getting off the car. X-ray anterior-posterior few.

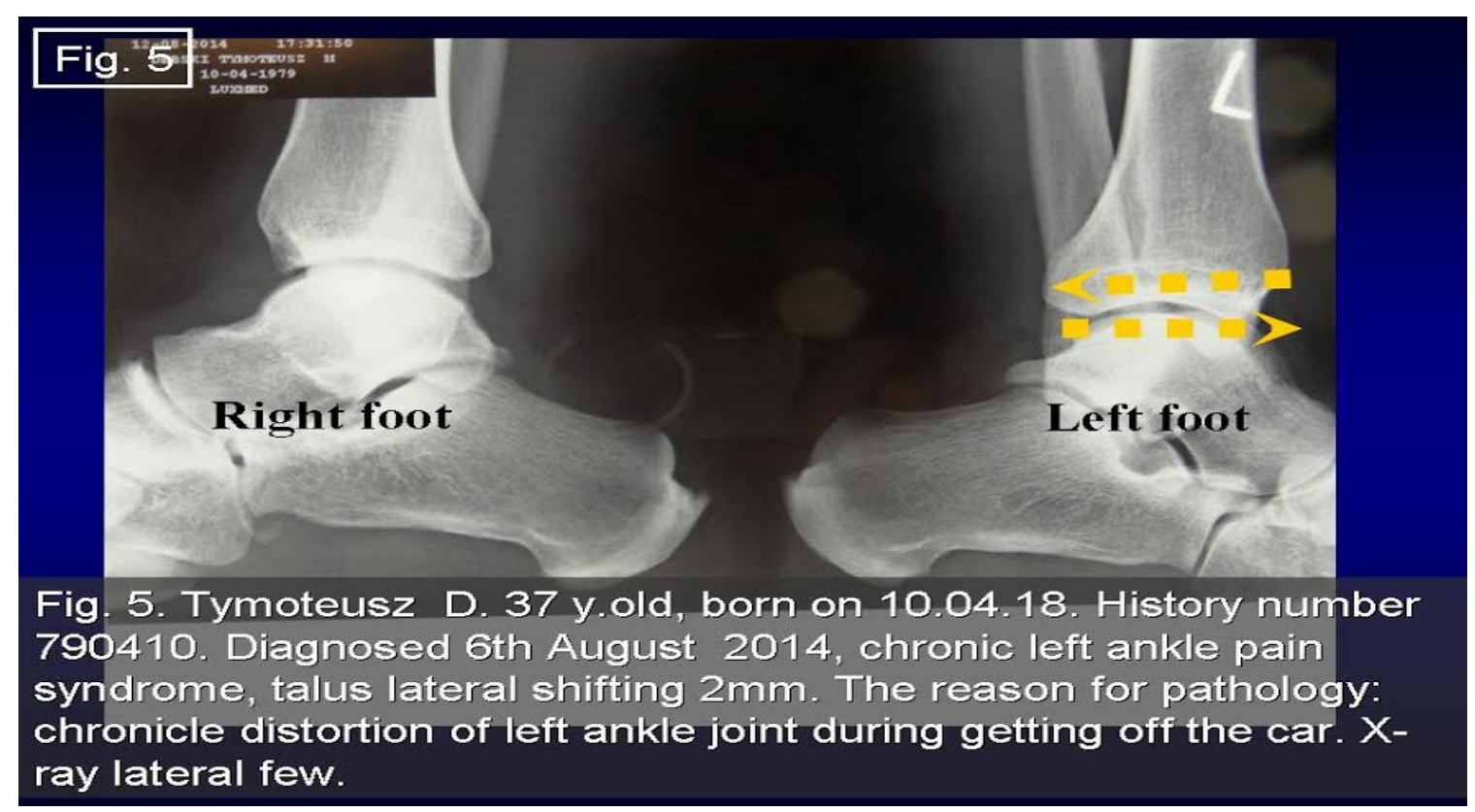

Fig. 5. Tymoteusz D. 37 y.old, born on 10.04.18. History number 790410. Diagnosed 6th August 2014, chronic left ankle pain syndrome, talus lateral shifting $2 \mathrm{~mm}$. The reason for pathology: chronicle distortion of left ankle joint during getting off the car. X-ray lateral few. 
Fig 6a, 6b. Przemyslaw W. 65 y. old, born 10.07.1949, treated since 19.01.2015 because of chronic pain of the knee and hip. Currently left foot pain. The reason of pain was diagnosed on the 25th of August 2015.

Swelling (arrow) with

thickening of soft tissue in sinus tarsi region, difficulty putting on shoes and walking The reason for pathology: chronicle distortion of left ankle joint during getting off the car. Anterior and posterior few of feet.

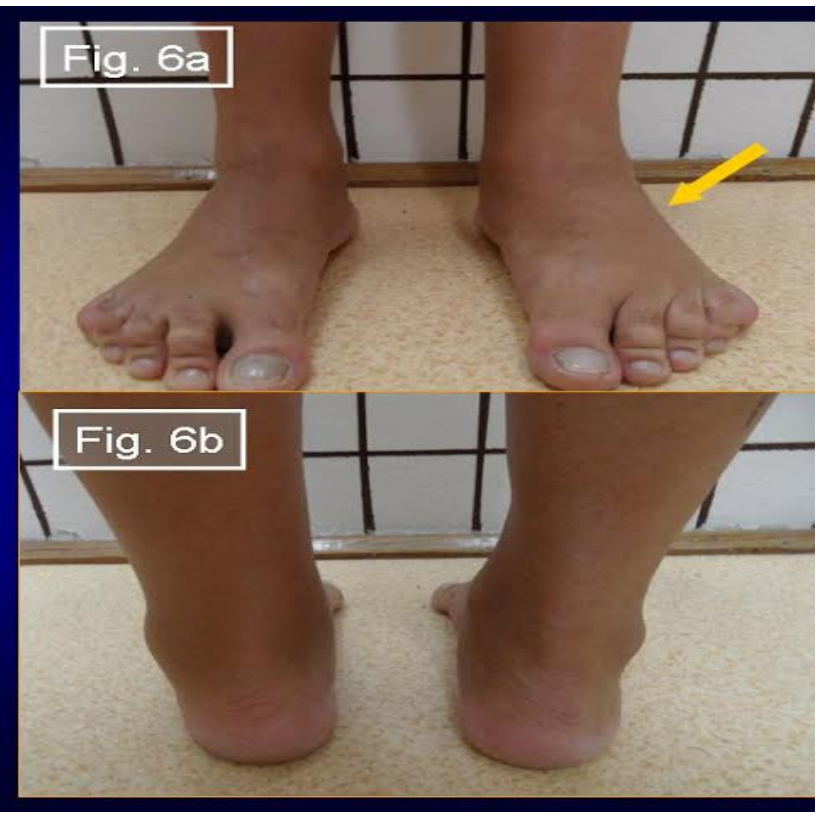

Fig6a, 6b. Przemyslaw W. 65 y. old, born 10.07.1949, treated since 19.01.2015 because of chronic pain of the knee and hip. Currently left foot pain. The reason of the pain was diagnosed on the 25th of August 2015. Swelling (arrow) with thickening of soft tissue in sinus tarsi region, difficulty putting on shoes and walking. The reason for pathology: chronicle distortion of left ankle joint during getting off the car. Anterior and posterior few of feet.

Fig. 7a, 7b. Przemyslaw W. $65 \mathrm{y}$. old, born 10.07.1949, treated since 19.01.2015, chronic pain of the knee and hip. Currently left foot pain. The reason of pain was diagnosed on the 25th of August 2015. Swelling (arrows) with thickening of soft tissue in sinus tarsi region, difficulty while putting on shoes and walking. The reason for pathology: chronicle distortion of left ankle joint during getting off the car. X-ray lateral few.

Fig. 7a, 7b. Przemyslaw W. 65 y. old, born 10.07.1949, treated since 19.01.2015, chronic pain of the knee and hip. Currently left foot pain. The reason of the pain was diagnosed on the 25th of August 2015. Swelling (arrows) with thickening of soft tissue in sinus tarsi region, difficulty putting on shoes and walking. The reason for pathology: chronicle distortion of left ankle joint during getting off the car. X-ray lateral few. 


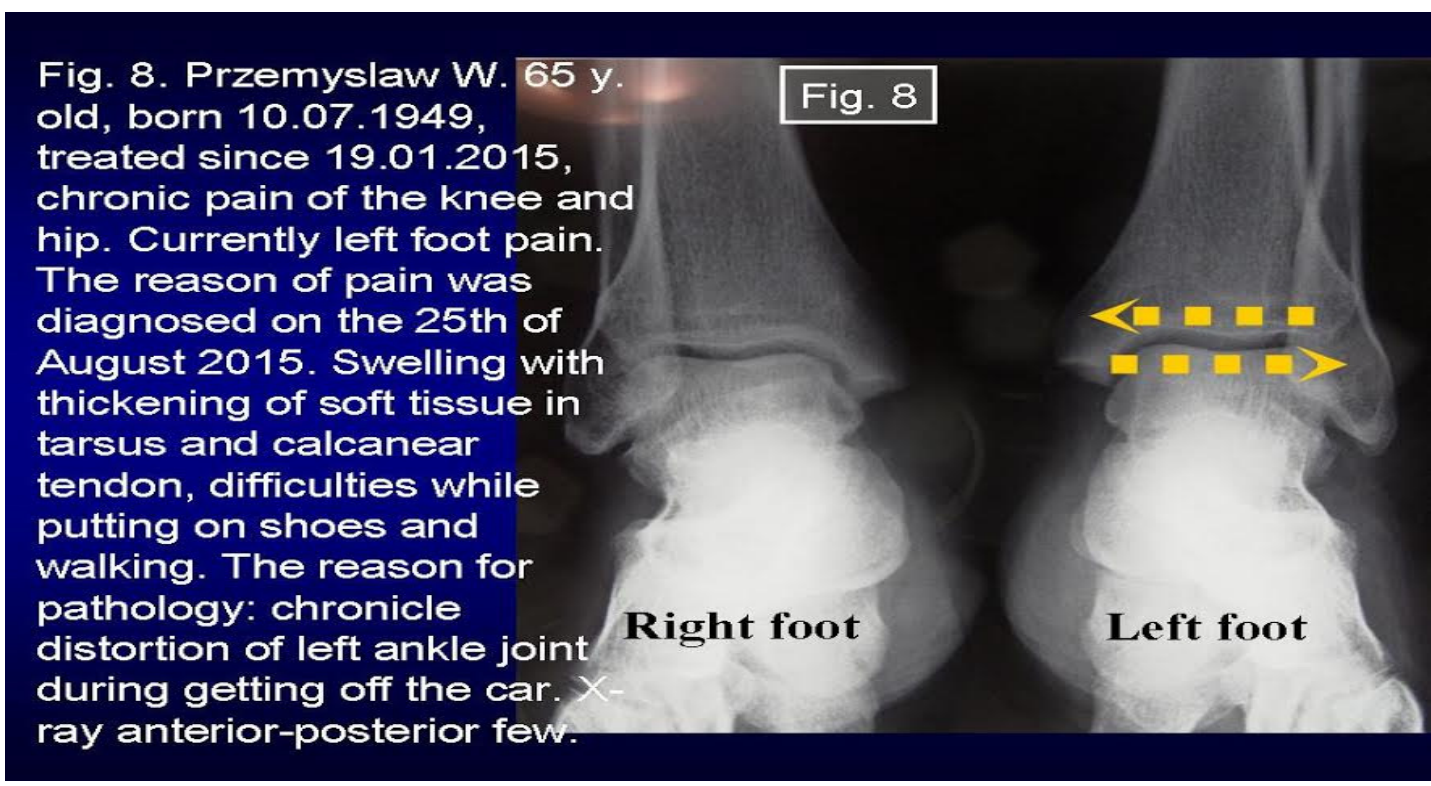

Fig. 8. Przemyslaw W. 65 y. old, born 10.07.1949, treated since 19.01.2015, chronic pain of the knee and hip. Currently left foot pain. The reason of the pain was diagnosed on the 25th of August 2015. Swelling with thickening of soft tissue in tarsus and calcanear tendon, difficulty putting on shoes and walking. The reason for pathology: chronicle distortion of left ankle joint during getting off the car. X-ray anterior-posterior few.

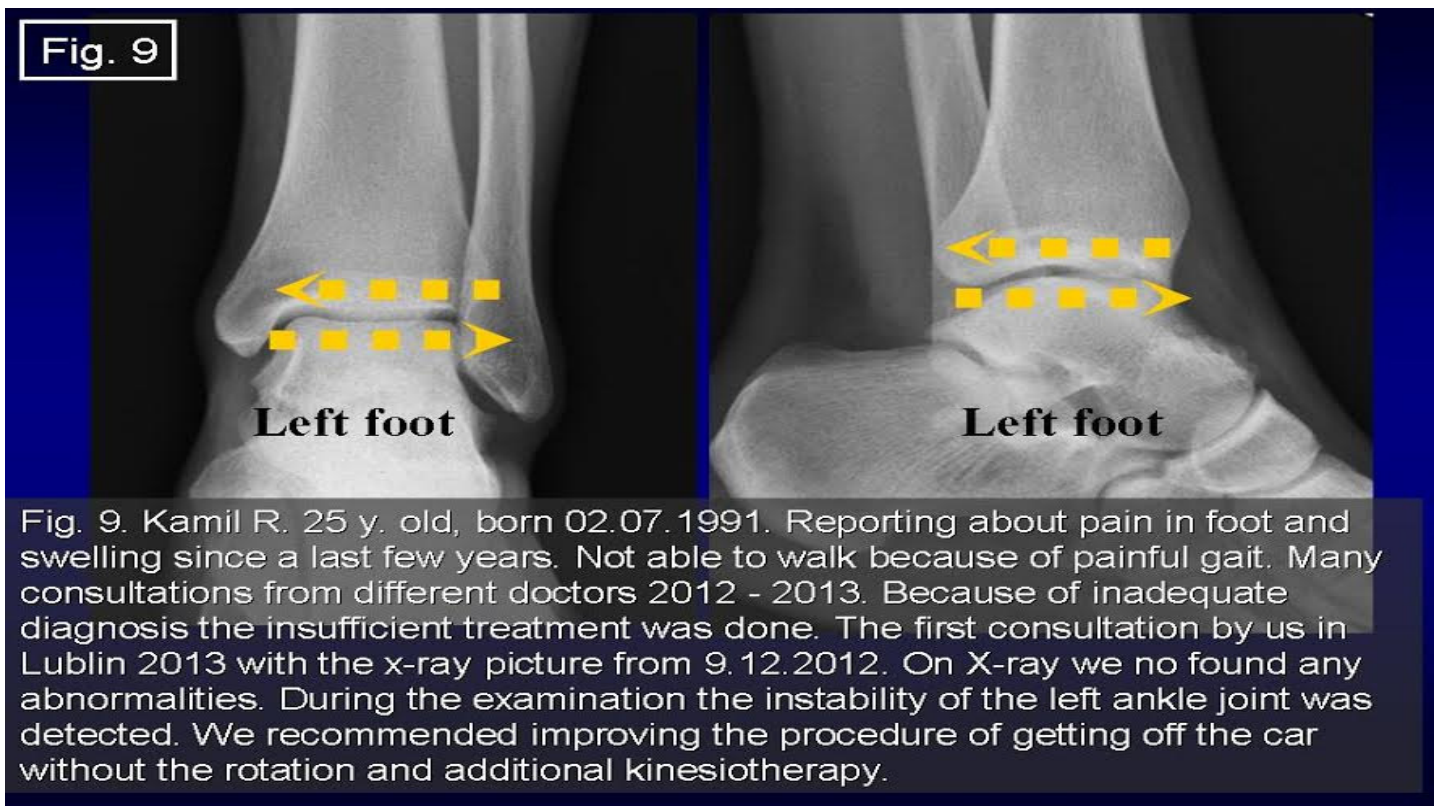

Fig. 9. Kamil R. 25 y. old, born 02.07.1991. Reporting about pain in foot and swelling since a last few years. Not able to walk because of painful gait. Many consultations from different doctors 2012 - 2013. Because of inadequate diagnosis the insufficient treatment was done. The first consultation by us in Lublin 2013 with the x-ray picture from 9.12.2012. On X-ray we no found any abnormalities. During the examination the instability of the left ankle joint was detected. We recommended improving the procedure of getting off the car without the rotation and additional kinesiotherapy. 


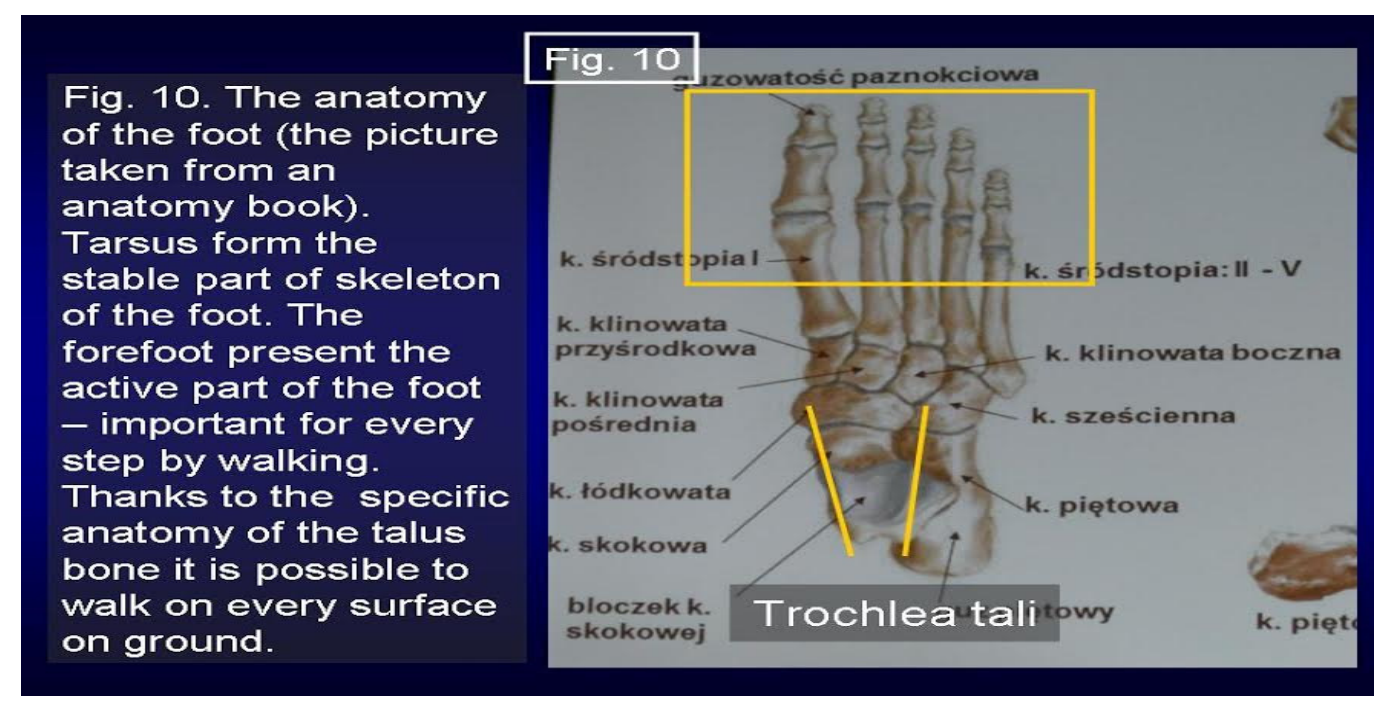

Fig. 10. The anatomy of the foot (the picture taken from an anatomy book). Tarsus form the stable part of skeleton of the foot. The forefoot presents the active part of the foot - important for every step by walking. Thanks to the specific anatomy of the talus bone it is possible to walk on every surface on ground.

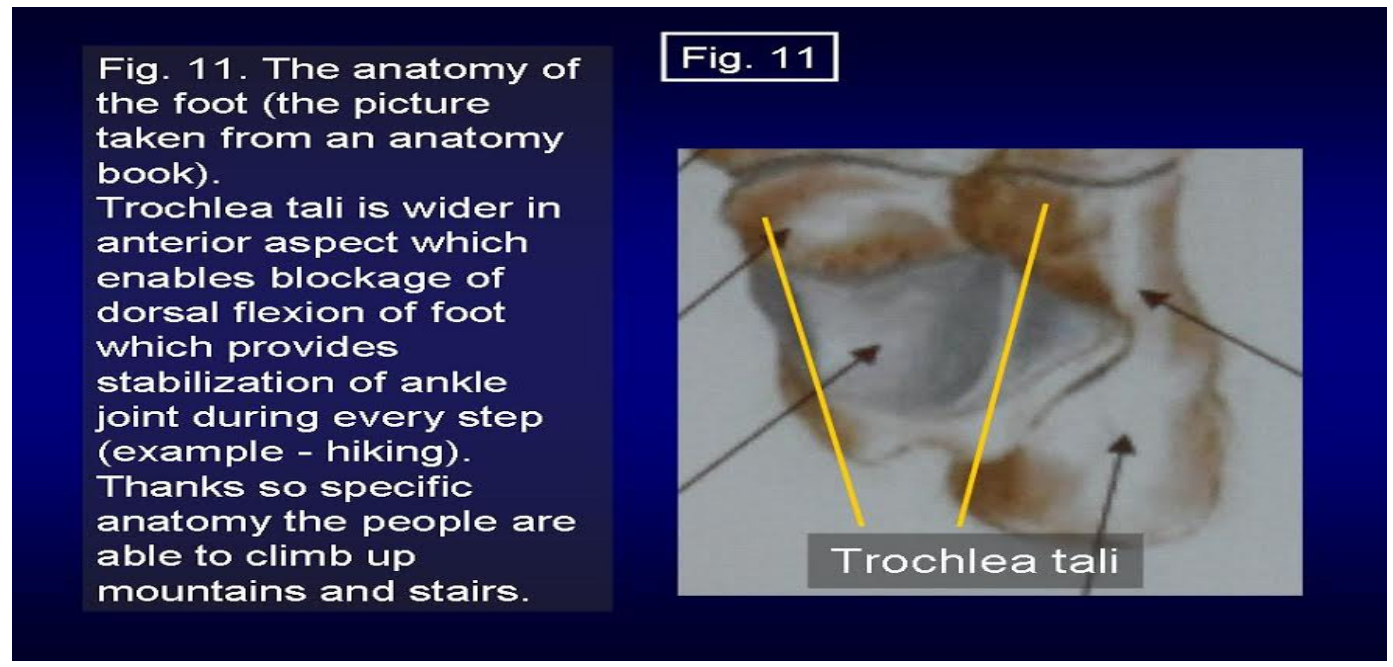

Fig. 11. The anatomy of the foot (the picture taken from an anatomy book).

Trochlea tali is wider in anterior aspect which enables blockage of dorsal flexion of foot which provides stabilization of ankle joint during every step (example - hiking). Thanks so specific anatomy the people are able to climb up mountains and stairs.

Citation: Dr. med. Jacek Karski, Prof. Tomasz Karski, Dr. Katarzyna Karska, Dr. med. Jarosław Pyrc "Ankle Joint Pathlology of Car Drivers and Passengers Case Report". American Research Journal of Medicine and Surgery; V3, I1; pp:1-12

Copyright (c) 2017, Dr. med. Jacek Karski, Prof. Tomasz Karski, Dr. Katarzyna Karska, Dr. med. Jarosław Pyrc, This is an open access article distributed under the Creative Commons Attribution License, which permits unrestricted use, distribution, and reproduction in any medium, provided the original work is properly cited. 